\title{
Stigma and psychological distress among pediatric participants in the FD/MAS Alliance Patient Registry
}

Amanda Konradie

\begin{abstract}
Background: Stigma, both enacted and internalized, is part of the illness experience of many chronic conditions / diseases and has been found to increase psychological distress, lower self-esteem, and impact social engagement lowering quality of life (QOL). Stigma among pediatric patients is of particular concern due to its potential impact on identity formation. Using patient data from the online FD/MAS Alliance Patient Registry (FDMASAPR), this study seeks to 1) determine levels of enacted and self-stigma in a pediatric population of fibrous dysplasia (FD) / McCune Albright syndrome (MAS) patients and 2) to explore the relationship between stigma and anxiety and depression.

Methods: This is a cross sectional analysis of deidentified self-report data from 18 pediatric patients. Key analytic variables include the Neuro-QOL stigma short form, the Hospital Anxiety and Depression Scale (HADS), diagnostic category and craniofacial involvement, and select demographics. Sample means and score distributions are examined. Bivariate relationships between stigma, anxiety and depression and patient's personal and medical characteristics are established through analysis of variance and correlation.
\end{abstract}

Results: Composite stigma levels for FD/MAS pediatric patients were comparable to those of children with multiple sclerosis, epilepsy, and muscular dystrophy. Self-stigma was more frequently reported than enacted/felt stigma, but few patients indicated complete freedom from either type of stigma. Diagnosis was significantly related to selfstigma. Significant bivariate relationships were found between depression and enacted/felt and self-stigma and between anxiety and self-stigma.

Conclusions: This study establishes the illness experience of pediatric patients with FD / MAS is impacted by stigma and suggests they should be regularly screened for stigma and psychological distress. It supports the integration of clinical psychologists/ therapists in regular patient care, referral of families to advocacy organizations, and indicates that rare disease patient registries can be a useful tool in efforts to improve the QOL of patients.

Keywords: Fibrous dysplasia, McCune Albright syndrome, Stigma, Self-stigma, Depression, Anxiety, Pediatrics, Children, Neuro-QOL, HADS

\section{Correspondence: akonradi@loyola.edu}

Department of Sociology, Loyola University Maryland, 4501 North Charles St.

Baltimore, MD 20210, USA

C C The Author(s). 2021 Open Access This article is licensed under a Creative Commons Attribution 4.0 International License, which permits use, sharing, adaptation, distribution and reproduction in any medium or format, as long as you give appropriate credit to the original author(s) and the source, provide a link to the Creative Commons licence, and indicate if changes were made. The images or other third party material in this article are included in the article's Creative Commons licence, unless indicated otherwise in a credit line to the material. If material is not included in the article's Creative Commons licence and your intended use is not permitted by statutory regulation or exceeds the permitted use, you will need to obtain permission directly from the copyright holder. To view a copy of this licence, visit http://creativecommons.org/licenses/by/4.0/ The Creative Commons Public Domain Dedication waiver (http://creativecommons.org/publicdomain/zero/1.0/) applies to the data made available in this article, unless otherwise stated in a credit line to the data. 


\section{Fibrous dysplasia}

Fibrous dysplasia (FD) is a rare mosaic bone disease in which fibro-osseous tissue replaces normal bone and marrow producing bones that may bend and fracture or expand beyond their typical limits [1]. Radiographically, the lesions resemble ground glass. Monostotic FD is most common in the rib, skull and femur; polyostotic is most common in the skull, mandible, pelvic bones and femur [2]. Mutations of cells in endocrine tissues also may cause a syndrome, called McCune Albright, that results in café-au-lait marks, precocious puberty; growth hormone excess, hyperthyroidism, hypercortisolism, and renal phosphate wasting [1]. MAS is estimated to comprise $5 \%$ of FD patients [3]. Bone lesions can result in a variety of functional problems depending on their location and cause pain [4-6]. New lesions typically stop emerging in adolescence, but the impact of FD/MAS is ongoing over the life course [1].

The difficulty of living with FD/MAS may extend beyond negotiating physical symptoms and emotional sequalae related to them. It may involve living in a body that others note for its differences [7]. The bowing and fracture of bones in the trunk and extremities may affect gait, stance, and ability to move fluidly or impede engagement in activities typical for an individual's age and gender, sometimes requiring assistive technology. Expansile bone grow may lead to facial asymmetry and distortion of features, impair hearing or vision, and cause the displacement of teeth $[6,8]$. Café-au-lait marks may disrupt the continuity of the skin's appearance. When others note physical differences and impairment resulting from FD/MAS they may stigmatize the whole individual $[7,9]$ and enact various forms of discriminatory behavior. Even when FD lesions are not visible because they grow inward in the skull, they may affect interaction. For example, those who experience chronic pain and seek strong analgesic medication may experience reproach for drug seeking behavior because they appear "normal" $[7,10]$.

\section{Stigma}

Stigma refers to the social marking and devaluation of specific qualities of humans, encompassing their physicality, their behaviors, and their membership in social groups [11]. Stigmatization can operate at the level of institutional practice, such that law, policy, and the built world marginalize people with certain traits. Individuals and groups can enact stigma and discriminate against, ostracize, and taunt those with certain devalued traits. And individuals with devalued traits can internalize the negative status and view and/or treat themselves as fundamentally less worthy (self-stigmatize). The different types of stigma tend to be mutually reinforcing [12-17]. Ill individuals often negotiate structural, interactional, and intrapersonal stigma in addition to adapting to their symptoms and treatment regimes.

\section{Stigma and illness}

One sector of illness research is concerned with the nature of stigma experienced by those with appearance affecting conditions, both congenital and emergent/accidental, including cleft lip and palate, cancer, burns, the impact of stigma on life satisfaction and on affected individual's coping strategies [18-21]. Another sector has focused on stigma experienced by those with more common chronic diseases/conditions, such as, HIV, mental illness, epilepsy, and autism, [22-29]. Rare and orphan diseases that involve a difference of appearance, such as Treacher Collins Syndrome, Crouzon Syndrome, Acromegaly, and vitiligo [30-32] have been studied, but little attention has been focused on how the rarity of diseases/conditions can itself be a unique source of stigma [33].

Studies of a variety of conditions/illnesses have found that enacted or anticipated stigma and self-stigma are associated with negative mental health outcomes, including depression, loss of confidence, low self-esteem, low adherence with medical treatment when compliance might bring on negative reactions from others, and selfisolation that limits an affected person's use of social support and economic participation [14, 34-37]. Stigma has also been linked to decisions to pursue aesthetic surgical treatment, with limited functional purpose, in order to reduce negative social responses [38].

While there is extensive research on the illness experience of children with craniofacial deformities and an effort to develop a specific quality of life instrument [39-42], more attention has been focused on how stigma affects adults with chronic illnesses than children [43]. Recent studies have found that chronically ill adolescents report feeling different at school and experiencing isolation and exclusion from peer activities [44], especially when their conditions were visible and limiting. Studies also show that chronically ill adolescent's stigma levels are significantly related to their levels of depression and anxiety [45]. Studies of adolescents with inflammatory bowel disease found illness stigma predicted levels of depression independently and indirectly in relation to their ability to communicate about their illness and their ability to belong to a social group $[46,47]$. Attention to the stigmatizing aspects of chronic illness in pediatric patients, especially adolescents, is important because they are developing a sense of self/identity and ways of being in the world that will influence their transition to living as independent adults, attending university and/or acquiring employment $[17,48]$. If stigma can be identified early in the illness experience, a variety of resources could be brought to bear to reduce its occurrence and limit its impact on the self of the affected individual and 
the development of problematic cognitive and psychological sequalae.

The health related quality of life (QOL) of FD/MAS patients is a growing concern of medical researchers [4, $5,7,49-52]$, however the stigma of FD is a new area of empirical research. Adults affected by craniofacial FD (CFD) with and without lesions in other areas of the body have reported experiencing outright discrimination and negative reactions to their appearance, including nonverbal recoil, verbal harassment, isolation, and rejection over the life course [7]. Some have also reported feeling deviant and lesser than others, not just physically different, and engaging in self-isolation [7]. One recent study of adults with CFD found the number of surgeries individual patients had was significantly related to their scores on measures of experienced/enacted stigma [53]. Another found that aesthetics was a commonly reported motivation for craniofacial surgical intervention and those with CFD who did and did not receive surgery had similar long term quality of life scores [54]. Stigma has not been explored in the pediatric FD/MAS population.

This study aims to describe the scope of stigma, both enacted/felt and internalized, in a population of pediatric FD/MAS patients and to explore whether stigma is related to depression, anxiety, and several medical and demographic variables.

\section{Methods}

\section{Study design}

This is a cross sectional analysis of deidentified selfreport data from the FD/MAS Alliance Patient Registry (FDMASAPR) [55]. The FDMASAPR is open to individuals from birth to age 70 with fibrous dysplasia and McCune Albright syndrome (fdmasregistry.org) and addresses aspects of the illness experience that are not central to medical treatment but are nevertheless important in the daily lives of patients. It consists of a battery of online questionnaires that document the extent of a participant's lesions and, if relevant, endocrine involvement, symptoms, surgical and medical treatments received and the motivations for them, quality of life and psychological distress, demographics, and access to treatment. The FD/MAS Alliance recruits participants through its contact database, featuring it in newsletters and in conference updates, and advertising it on the website and through Facebook groups and Twitter. Consenting protocols for the FDMASAPR are reviewed by New England IRB (Needham, MA). All adults (patients and caretakers) complete an electronic consenting process and minors must complete an electronic assent process before entering responses, which creates a digital record of their consent/assent.

In December 2018, when a deidentified FDMASAPR data set was secured, at least one questionnaire had been completed for 83 pediatric patients (1 to 17 years of age). Eighteen, that constitute this sample, had provided comprehensive demographic and bone involvement information and had completed the two key self-report measures required for this analysis. The university IRB declined to subject use of this deidentified data set to further review.

\section{Measures}

The study incorporated the FDMASAPR participant's age, gender, race, and both parent's educational attainment levels, reported medical diagnosis, as monostotic FD, polyostotic FD or FD with McCune Albright Syndrome, and presence of craniofacial involvement.

The 8-item Neuro-QOL stigma pediatric self-report short form ascertains patient's "perceptions of self and publically [sic] enacted negativity, prejudice and discrimination as a result of disease-related manifestations" [56]. The question time frame is "lately" and, all but one question begins with the phrase "because of my illness." Answers encompass never (1), rarely (2), sometimes (3), often (4) and always (5). The stigma module of the Neuro-QOL was calibrated on children with epilepsy and muscular dystrophy [57]. It was further validated on children with epilepsy; stigma scores discriminated among patients with differing quality of life and severity of illness [51]. The Neuro-QOL stigma short form has not been widely used in pediatric research.

Following the Neuro-QOL scoring protocol, the eight items were combined to produce a composite stigma score (8-40) and normed T-scores were created [56]. For the purposes of calculating the composite, two missing items are replaced with a mean score. Neuro-QOL $\mathrm{T}$-scores above 50 indicate a greater level of stigma than the mean of the clinical reference population of children suffering from neurological conditions [56].

The adult version of the stigma scale has been divided into enacted and self-stigma in FD research $[53,54]$ as described by Molina and colleagues [58]. Following that practice, the pediatric scale was disaggregated. To create the two sub scales used in this study the questions were first sorted by their apparent meaning. Initially, two groups of questions were created 1, 3, 5, 6 (enacted stigma) and 2, 4, 7 and 8 (self-stigma). Then, a correlation matrix was created to determine if the questions assigned to either scale had significant and high correlations with others that were similarly assigned. As a result of this review, question 8 was determined to reflect anticipation of stigma not self-stigma and the second category was expanded to encompass enacted/felt stigma. Chronbach's alpha was computed for the two subscales and indicated adequate internal consistency for their use in analysis: enacted/felt stigma (.935) and self-stigma (.816). 
The questions that constitute the enacted/felt scale used in this study address other's demeaning actions or anticipated actions: other's avoidance (1), teasing (3), unfair treatment (5), and ignoring of the respondent's good qualities (6) resulting in an expectation of difficult interaction (8). The three questions addressing self-stigma used in this study ask about the respondent's feelings of difference (7), embarrassment (4) and being left out (2) as a result of their illness.

The Hospital Anxiety and Depression scale (HADS) is a 14 item self-report questionnaire that asks patients how often they have experienced specific feelings in the past week. Answer values range from 0 to 3 and are added to produce anxiety and depression scores, from 0 to $21[59,60]$. The HADS is validated on general and specific disease populations for adults; it is used extensively in research, especially in Europe [61]. The HADS has been validated on generic populations of adolescents 12 to 17 in the US [62] and Sweden [63]. However, studies of healthy and clinically depressed adolescents and young adults suggest the HADS underpredicts depression in this age range $[64,65]$. Two studies have reported significant gender differences in HADS scores among adolescents and young adults $[62,63]$.

\section{Analysis}

Statistical analysis was conducted with SPSS version 26. Sample means and score distributions were examined and compared to the Neuro-QOL benchmark via t-test. Analysis of variance and Pearson correlation were used to explore bivariate relationships between stigma, anxiety and depression and patient's personal and medical characteristics.

\section{Results}

\section{Participant characteristics (see Table 1)}

The sample consisted of 18 predominately white (94\%) and male (61\%) minors with a mean age of 12.9 years (median 13, range 8 to 17). Most of participant's parents, $83 \%$ of mothers and $65 \%$ of fathers, had completed college. Polyostotic FD was reported by $67 \%$ of participants, followed by McCune Albright Syndrome (22\%) and monostotic FD (11\%). The majority (61\%) did not have craniofacial lesions. All demographic data was complete.

\section{Stigma}

Table 2 depicts univariate analysis of the individual items of the Neuro-QOL Stigma questionnaire and means, standard deviations and medians of the three scales derived from those measures: composite $\mathrm{T}$-score, enacted/felt stigma and self-stigma. Raw total scores ranged from 8 to 24 out of a possible total of 50 . Three individuals reported never experiencing any type of stigma (a raw score of 8 ) and four scored 24, an average
Table 1 Demographics and medical characteristics

\begin{tabular}{|c|c|c|}
\hline \multicolumn{3}{|l|}{ Age } \\
\hline Mean & 12.9 & \\
\hline SD & 2.8 & \\
\hline \multirow[t]{2}{*}{ Median } & 13 & \\
\hline & Frequency & $\%$ \\
\hline \multicolumn{3}{|l|}{ Gender } \\
\hline Male & 11 & 61 \\
\hline Female & 7 & 39 \\
\hline \multicolumn{3}{|l|}{ Race } \\
\hline White & 17 & 94 \\
\hline Nonwhite & 1 & 6 \\
\hline \multicolumn{3}{|l|}{ Mother's Education } \\
\hline High school or less & 2 & 11 \\
\hline Some College & 1 & 6 \\
\hline College or more & 15 & 83 \\
\hline \multicolumn{3}{|l|}{ Father's education } \\
\hline High school or less & 0 & 0 \\
\hline Some College & 6 & 35 \\
\hline College or more & 11 & 65 \\
\hline \multicolumn{3}{|l|}{ Diagnosis } \\
\hline Monostotic & 2 & 11 \\
\hline Polyostotic & 12 & 67 \\
\hline McCune Albright & 4 & 22 \\
\hline \multicolumn{3}{|l|}{ Craniofacial } \\
\hline No & 11 & 61 \\
\hline Yes & 7 & 39 \\
\hline
\end{tabular}

of "sometimes" responses. Feeling that their good points were ignored was the least common experience among participants, with $61 \%$ of the sample reporting it "never" occurred. "Often" answers were most common in relation to feeling left out. No participants reported they "always" experienced any kind of stigma. The mean composite stigma $\mathrm{T}$-score was 49.56. The median $\mathrm{T}$ score was 52, comparable to consistently responding "rarely." The minimum enacted/felt stigma raw score was 5 points, reflecting no stigma (6 individuals, 35\%); the maximum was 15 points. The mean raw score for enacted/felt stigma was 8.6 points; $34 \%$ of the possible total score of 25 points. The minimum self-stigma raw score was 3 points, reflecting no stigma (3 individuals/ $17 \%)$ and the maximum score was 12 points. The mean raw score for self-stigma was 7.2 points; $48 \%$ of the possible total score of 15 points.

Bivariate analysis of stigma scale scores and participant characteristics revealed father's education and diagnosis were significantly related to stigma T-scores (see Table 3) Bonferroni post hoc tests revealed participants with 
Table 2 Stigma univariate statistics

\begin{tabular}{|c|c|c|c|c|c|c|c|c|c|c|}
\hline \multirow[t]{2}{*}{ T-score Distributions } & 37.1 & 42.8 & 44.6 & 46.3 & 47.7 & 49.9 & 50.8 & 53.3 & 54 & 57.7 \\
\hline & 3 & 1 & 1 & 1 & 1 & 1 & 1 & 3 & 2 & 4 \\
\hline \multirow[t]{2}{*}{ Score Distributions by Item } & Subscale & Never & Rarely & Sometimes & Often & Always & Mean & SD & $\mathrm{N}$ & \\
\hline & & (1) & (2) & (3) & (4) & $(5)$ & & & & \\
\hline 1. Others avoided me & felt & 8 & 5 & 5 & 0 & 0 & 1.88 & 0.86 & 18 & \\
\hline 2. I felt left out & self & 6 & 2 & 3 & 7 & 0 & 2.61 & 1.33 & 18 & \\
\hline 3. Others made fun of me & felt & 9 & 6 & 3 & 0 & 0 & 1.65 & 0.79 & 18 & \\
\hline 4. I felt embarrassed & self & 7 & 5 & 5 & 1 & 0 & 2.00 & 0.97 & 18 & \\
\hline 5. I was treated unfairly & felt & 8 & 5 & 2 & 2 & 0 & 1.88 & 1.05 & 17 & \\
\hline 6. Others ignored my good points & felt & 11 & 5 & 2 & 0 & 0 & 1.53 & 0.72 & 18 & \\
\hline 7. I felt different & self & 3 & 4 & 8 & 3 & 0 & 2.61 & 0.98 & 18 & \\
\hline $\begin{array}{l}\text { 8. I avoided making friends to avoid talking } \\
\text { about illness }\end{array}$ & felt & 10 & 5 & 3 & 0 & 0 & 1.65 & 0.79 & 18 & \\
\hline Stigma Scales & $\begin{array}{l}\text { Composite T- } \\
\text { score } \\
N=18\end{array}$ & $\begin{array}{l}\text { Enacted/Felt } \\
\text { Stigma } \\
N=17\end{array}$ & $\begin{array}{l}\text { Self- } \\
\text { Stigma } \\
N=18\end{array}$ & & & & & & & \\
\hline Min-Max & & 5 to 25 & 3 to 15 & & & & & & & \\
\hline Mean & 49.56 & 8.6 & 7.2 & & & & & & & \\
\hline SD & 7.28 & 3.8 & 2.8 & & & & & & & \\
\hline Median & 52 & 7 & 8 & & & & & & & \\
\hline Minimum score & 31.1 & 5 & 3 & & & & & & & \\
\hline Maximum score & 57.7 & 15 & 12 & & & & & & & \\
\hline Mean as $\%$ of Possible Total & & $34 \%$ & $48 \%$ & & & & & & & \\
\hline
\end{tabular}

Table 3 Stigma x patient characteristics

\begin{tabular}{cccc}
\hline Variable & Stigma T Score & Enacted/Felt Stigma & Self- Stigma \\
\hline Age & & & \\
$R^{2}$ & 0.032 & 0.261 & -0.035 \\
$P$ & 0.901 & 0.312 & 0.891 \\
Gender & & & \\
$F$ & 0.002 & 0.057 & 0.330 \\
$P$ & 0.961 & 0.815 & 0.573 \\
Mothers Education & & \\
$F$ & 1.700 & 0.484 & 1.197 \\
$P$ & 0.216 & 0.626 & 0.329 \\
Father's Education & & \\
$F$ & 4.880 & 3.755 & 4.087 \\
$P$ & $0.043^{*}$ & 0.073 & 0.061 \\
Diagnosis & & & 3.718 \\
$F$ & 5.640 & 1.635 & $0.049^{*}$ \\
$P$ & $0.015^{*}$ & 0.230 & 0.180 \\
Craniofacial & & & 0.667 \\
$F$ & 0.563 & 0.759 & \\
$P$ & 0.464 & 0.397 & \\
\hline
\end{tabular}

* Indicates significant $p$ values monostotic FD had, on average, significantly $(p<.05)$ higher scores than those with polyostotic FD $(+13.15)$ and FD/MAS (+16.23). Diagnosis was significantly related to self-stigma as well, although specifics were not established through Bonferroni analysis. No patient characteristics were significantly associated with enacted/felt stigma.

\section{Anxiety and depression (see Table 4 for univariate and bivariate results)}

Anxiety scores ranged from 0 to 14 , with a mean of 7.37; ten respondents (55\%) scored 8 or more indicating clinical levels of anxiety. Mean depression scores ranged from 0 to 8 , with a mean of 2.68 ; one respondent scored as clinically depressed. Bivariate analysis found participant sex was significantly associated with depression and no patient characteristics were associated with anxiety. Depression scores were significantly and strongly correlated with Stigma Tscores $\left(R^{2}=.61\right)$ and enacted/felt stigma $\left(R^{2}=.75\right)$ and moderately correlated with self-stigma $\left(R^{2}=.45\right)$. Anxiety scores were significantly and strongly correlated with self-stigma $\left(R^{2}=.60\right)$ and moderately correlated with composite stigma $\mathrm{T}$-scores $\left(R^{2}=.50\right)$. 
Table 4 Hospital anxiety and depression scales

\begin{tabular}{|c|c|c|c|c|}
\hline & Mean & SD & Median & Range \\
\hline \multicolumn{5}{|l|}{ Univariate } \\
\hline HADS Anxiety & 7.00 & 3.72 & 8 & 14 \\
\hline HADS Depression & 2.61 & 2.50 & 2 & 8 \\
\hline \multicolumn{5}{|l|}{ Bivariate Relationships } \\
\hline Variable & & Anxiety & Depression & \\
\hline \multirow[t]{2}{*}{ Age } & $R^{2}$ & 0.207 & 0.288 & \\
\hline & $p$ & 0.396 & 0.232 & \\
\hline \multirow[t]{2}{*}{ Gender } & $\mathrm{F}$ & 3.023 & 6.140 & \\
\hline & $p$ & 0.100 & $0.024^{*}$ & \\
\hline \multirow[t]{2}{*}{ Mothers Education } & $\mathrm{F}$ & 0.368 & 0.321 & \\
\hline & $p$ & 0.698 & 0.730 & \\
\hline \multirow[t]{2}{*}{ Father's Education } & $\mathrm{F}$ & 1.014 & 0.864 & \\
\hline & $p$ & 0.329 & 0.366 & \\
\hline \multirow[t]{2}{*}{ Diagnosis } & $\mathrm{F}$ & 0.134 & 0.106 & \\
\hline & $p$ & 0.876 & 0.900 & \\
\hline \multirow[t]{2}{*}{ Craniofacial } & $\mathrm{F}$ & 0.290 & 1.282 & \\
\hline & $p$ & 0.597 & 0.273 & \\
\hline \multirow[t]{2}{*}{ Stigma T-Score } & $R^{2}$ & 0.501 & 0.608 & \\
\hline & $p$ & $0.034^{*}$ & $0.007^{*}$ & \\
\hline \multirow[t]{2}{*}{ Enacted/Felt Stigma } & $R^{2}$ & 0.454 & 0.747 & \\
\hline & $p$ & 0.067 & $0.001^{*}$ & \\
\hline \multirow[t]{2}{*}{ Self-Stigma } & $R^{2}$ & 0.595 & 0.453 & \\
\hline & $p$ & $0.009^{*}$ & $0.02^{*}$ & \\
\hline
\end{tabular}

${ }^{*}$ Denotes significant $p$ values

\section{Discussion}

Four fifths of the pediatric FD patients in this sample experienced some level of illness related stigma. Discriminatory acts, ridicule and avoidance were reported and anticipated. These children also did not categorically reject the idea that their illness made them different and possibly inferior to others, evidence of stigma internalization. On average their responses to questions associated with self-stigma indicated greater frequency than enacted/felt stigma. Higher levels of self-stigma have been found by other investigators and may indicate that FD, at least in some contexts, has a low level of disruptiveness on interaction and / or is concealable. For example, higher levels of enacted stigma were reported for more socially disruptive muscular nerve disorders than peripheral nerve disorders [36]. The child with FD knows that they are subject to being discredited and rejected even when it does not occur. Children who fear being publicly exposed as lesser may also engage in defensive isolation, which minimizes the likelihood of direct discrimination. The finding of an association between diagnosis and the composite stigma measure and self-stigma, but not enacted/felt stigma is consistent with this. Children may associate greater physical involvement with FD with greater deviation from "normal"; although their physical variability may not be readily apparent to others. The bivariate relationship between stigma and father's education may reflect the impact of social class position on likelihood of facing discrimination, such that children with less educated fathers have lower social status and generally face more discrimination. Or, less educated fathers may be less accepting of medically complex children, especially boys who cannot live up to physical ideals of masculinity and thus serve as a conduit of stigma (parent reader communication).

This study found the mean composite stigma score for children with FD was similar to children with serious chronic neurological conditions. Higher scores for enacted/felt stigma were associated with higher levels of depression, but not with anxiety. Self-stigma was associated with anxiety and depression. While this crosssectional study does not establish a causal relationship, the literature from chronic illness suggests that stigma increases psychological distress $[15,45,46]$. These results point to the desirability of incorporating screening for stigma into the structure of pediatric care for FD [66]. Adults with FD/MAS reported a range of responses to enacted and felt stigma, including self-isolation [7]. There is reason to be concerned about adolescents turning to strategies of self-isolation as a protective measure, as it can affect their ability to form relationships and may impact their later participation in higher education and employment [67].

Patients and families should be aggressively referred to support groups and patient organizations [17, 68]. Such communities can offer proactive coping strategies and provide a disability rights orientation that may help encourage frank discussion instead of denial and silence to normalize the patient identity and possibly limit internalization of stigma, as well as support parents of affected children [17, 69-71]. Programs can help children and adolescents with FD/MAS manage their illness identity and develop skills for troubled interactions with others [7]. Parents can also be helped to manage courtesy stigma and the stigma of being a bad parent, which can influence their parenting style in ways that may be detrimental to the identity development and coping strategies adopted by their children [72-75]. Given the rarity of FD/ MAS and the geographic dispersal of patients, online strategies for service delivery should be explored, such as the CBT program FaceIT [76]. Finally, attention should be given to ensuring that medical providers, who have an immense power to shape how children/adolescents view themselves and their condition, consistently use language that is not demeaning 
and that emphasizes abilities rather than deficits (parent reader communication).

Evidence supports psychosocial intervention. Research has established the efficacy of a combination of psychosocial education and cognitive behavior therapy (CBT) $[66,77-79]$ or narrative practices [80] to reduce selfstigmatization among those with chronic stigmatizing illnesses. Studies show that providing social skills training improves the ability of children with craniofacial differences to initiate interactions [81]. Social skills training, CBT to heighten self-esteem, and guidance to manage emotional reactions, have also been found effective to reduce teasing $[82,83]$ of/by children.

This study has several limitations. This pediatric sample from the FDFPR is small with low power, perhaps too small to capture the significant impact of demographics and disease characteristics on stigma, anxiety and depression [72]. The sample is also skewed to white children with well-educated parents limiting its generalizability. Pain was not included as a control variable although chronic pain has been found to correlate with stigma [84] and with depression [85, 86]. Finally, the cross-sectional design precludes establishing causality.

This study may also underestimate the level of psychological distress associated with FD/MAS for several reasons. The Neuro-QOL stigma measure is limited; it does not encompass the full scope of enacted and self-stigma. For example, it does not address appearance related stigma, which can be an important issue for those with craniofacial FD or with visible café-au lait marks. The HADS attends only to aspects of depression related to the loss of pleasure response (anhedonia) [59] and does not record aspects of feeling sad or blue often associated with medical illness [87]. It has also been reported to under estimate depression in adolescents $[64,65]$. Like prior research, this study found participant gender significantly contributed to explaining depression [62,63]. It is possible that the greater proportion of males in this sample skews the reported mean levels of depression downward.

This study examines the existence of stigma and its relationship to anxiety and depression through short quantitative screening measures. Further investigation of stigma among pediatric FD patients using more comprehensive measures should be undertaken. Qualitative research is also needed to develop an understanding of the coping strategies that FD / MAS patients have developed to deal with enacted/felt and self-stigma and the parenting styles and educational accommodations that provide the most protection to children [73].

\section{Conclusion}

This first study of stigma in a population of pediatric FD / MAS patients found that they experienced it at levels comparable to children with other chronic and stigmatizing diseases/conditions. Stigma among pediatric patients with FD / MAS was also significantly associated with measures of anxiety and depression. These results speak to the potential of voluntary rare patient registries to address the broader illness experience and improve quality of life [88-90]. Registries created and sustained by advocacy organizations, including patients and their caretakers, can provide leadership by incorporating psychological and social measures that can lead to more holistic treatment over the life course.

\section{Abbreviations \\ CFD: Craniofacial fibrous dysplasia; FD: Fibrous dysplasia; FD/MASA: FD/MAS Alliance; FDMASAPR: FD/MAS Alliance Patient Registry; HADS: Hospital Anxiety and Depression scale; MAS: McCune Albright syndrome}

\section{Acknowledgements}

Tovah Burstein generously assisted with piloting the use of data in the Fibrous Dysplasia Foundation Patent Registry (now FD/MAS Alliance Patient Registry). Dr. Andrea Burke, MD, DDS collaborated to secure data from the Fibrous Dysplasia Foundation (now FD/MAS Alliance). Fibrous Dysplasia caretakers and former Fibrous Dysplasia Foundation board members Lisa Heral, RN, BSN and Catherine Fairchild, Esq. provided useful commentary on a draft of this manuscript.

\section{Author's contributions}

All data analysis and writing accomplished by the author. The author(s) read and approved the final manuscript.

\section{Authors' information}

Amanda Konradi, Associate Professor of Sociology, Loyola University Maryland. Board of Directors Fibrous Dysplasia Foundation, Secretary \& Executive Committee, 2004-2016; Acting President 2015-2016; Patient Registry Steering Committee member 2010 - present.

\section{Funding}

The Oral Maxillofacial Foundation funded acquisition of the data for another project. No funding was received to assist with the preparation of this manuscript.

\section{Availability of data and materials}

The data that support the findings of this study are available from the FD/ MAS Alliance but restrictions apply to the availability of these data, which were used under license for the current study, and so are not publicly available. Data are however available from the author upon reasonable request and with permission of the FD/MAS Alliance.

\section{Declarations}

\section{Ethics approval and consent to participate}

Data collection protocols for the FD/MAS Alliance Patient Registry (FDFPR) are reviewed by New England IRB (Needham, MA) and are in accordance with the 1964 Helsinki declaration and its later amendments or comparable ethical standards. Deidentified data provided for this study by the Fibrous Dysplasia Foundation was deemed exempt from further review by the Loyola University Maryland IRB.

Informed consent/assent was obtained from all individual participants included in the study by the FD/MAS Alliance. Adults and minors provide their consent by clicking on an appropriate series of buttons, which creates a record of their agreement and allows them access to the registry surveys.

\section{Consent for publication}

NA

Competing interests

The author has no relevant financial or non-financial interests to disclose. 


\section{Received: 24 November 2020 Accepted: 7 April 2021}

\section{Published online: 14 April 2021}

\section{References}

1. Boyce A, Florenzano P, de Castro LF, Collins MT. Fibrous dysplasia/McCuneAlbright syndrome. In: Gene reviews. Seattle: University of Washington; 2019. p. 1993-2020. https://www.ncbi.nlm.nih.gov/books/.

2. Kushchayeva YS, Kushchayev SV, Glushko TY, Tella SH, Teytelboym OM, Collins MT, et al. Fibrous dysplasia for radiologists: beyond ground glass bone matrix. Insights Imaging. 2018;9(6):1035-56. https://doi.org/10.1007/ s13244-018-0666-6.

3. Utriainen P, Valta H, Björnsdottir S, Mäkitie O, Horemuzova E. Polyostotic fibrous dysplasia with and without McCune-Albright syndrome-clinical features in a Nordic pediatric cohort. Front Endocrinol. 2018;9:96. https://doi. org/10.3389/fendo.2018.00096.

4. Kelly MH, Brillante B, Collins MT. Pain in fibrous dysplasia of bone: agerelated changes and the anatomical distribution of skeletal lesions. Osteoporos Int. 2008;19(1):57-63. https://doi.org/10.1007/s00198-007-0425-X.

5. Kelly MH, Brillante B, Kushner H, Gehron Robey P, Collins MT. Physical function is impaired but quality of life preserved in patients with fibrous dysplasia of bone. Bone. 2005;37(3):388-94. https://doi.org/10.1016/j.bone.2 005.04.026.

6. Burke A, Boyce AM, Collins MT. Fibrous dysplasia of bone: craniofacial and dental implications. Oral Dis. 2017;23(6):697-708. https://doi.org/10.1111/ odi. 12563.

7. Konradi A. Treating the "illness" of Cherubism and craniofacial fibrous dysplasia: addressing the stigma of craniofacial difference. J Law Med Ethics. 2017:45(4):582-95. https://doi.org/10.1177/1073110517750598.

8. Boyce AM, Burke A, Peck CC, DuFresne CR, Lee JS, Collins MT. Surgical management of polyostotic craniofacial fibrous dysplasia: long term outcomes and predictors for postoperative regrowth. Plast Reconstr Surg. 2016;137(6):1833-9. https://doi.org/10.1097/PRS.0000000000002151.

9. Macgregor FC. Facial disfigurement: problems and management of social interaction and implications for mental health. Aesthetic Plast Surg. 1990; 14(1):249-57. https://doi.org/10.1007/BF01578358.

10. Thomas S. A phenomenological study of chronic pain. West J Nurs Res. 2000;22:683-705.

11. Goffman E. Stigma: notes on the management of spoiled identity. New York: Touchstone; 1986.

12. Link BG, Phelan JC. Conceptualizing stigma. Annu Rev Sociol. 2001;27: 363-85.

13. Green S, Davis C, Karshmer E, Marsh P, Straight B. Living stigma: the impact of labeling, stereotyping, separation, status loss, and discrimination in the lives of individuals with disabilities and their families. Sociol Inq. 2005;75(2): 197-215. https://doi.org/10.1111/j.1475-682X.2005.00119.x.

14. Bos AER, Pryor JB, Reeder GD, Stutterheim SE. Stigma: advances in theory and research. Basic Appl Soc Psychol. 2013;35:1-9.

15. Rao D, Choi SW, Victorson D, Bode R, Peterman A, Heinemann A, et al. Measuring stigma across neurological conditions: the development of the stigma scale for chronic illness (SSCI). Qual Life Res. 2009;18(5):585-95. https://doi.org/10.1007/s11136-009-9475-1.

16. Corrigan PW, Watson AC. The paradox of self-stigma and mental illness. Clin Psychol Sci Pract. 2002;9:35-53.

17. Elkington KS, Hackler D, McKinnon K, Borges C, Wright ER, Wainberg ML. Perceived mental illness stigma among youth in psychiatric outpatient treatment. J Adolesc Res. 2012;27(2):290-317. https://doi.org/10.1177/0743 558411409931.

18. Bonanno A, Esmaeli B. Cancer and facial disfigurement: reducing survivors' stigma in social interaction. Clin J Oncol Nurs. 2012;41:153-9.

19. Roberts RM. Discrimination among adults with craniofacial conditions. J Craniofac Surg. 2014;25(1):77-81. https://doi.org/10.1097/SCS.0b013e31 82a2e005.

20. Hanus SH, Bernstein NR, Kapp KA. Immigrants into society: children with craniofacial anomalies. Clin Pediatr (Phila). 1981;20(1):37-41. https://doi.org/1 $0.1177 / 000992288102000105$.

21. Strauss RP, Newell R, Marks I. "Only skin deep": health, resilience, and craniofacial care. Cleft Palate Craniofac J. 2001;38(3):226-30. https://doi.org/1 0.1597/1545-1569_2001_038_0226_osdhra_2.0.co_2.

22. Crandall CS, Moriarty D, Pan AW, Chung L, Fife BL, Hsiung PC. Physical illness stigma and social rejection. Int J Rehabil Res. 2007;34:30 67; 235$83 ; 238$.
23. Fife $B L$, Wright ER. The dimensionality of stigma: a comparison of its impact on the self of persons with HIV/AIDS and cancer. J Health Soc Behav. 2000;41(1):50-67.

24. Livingston JD, Boyd JE. Correlates and consequences of internalized stigma for people living with mental illness: a systematic review and meta analysis. Soc Sci Med. 2010;71:2150-61.

25. Clement S, Brohan E, Thornicroft G, Slade M, Brohan E. Experiences of mental illness stigma, prejudice and discrimination: a review of measures. BMC Health Serv Res. 2010;10 Generic. http://proxy-In.researchport.umd.edu/ login?url=http://search.ebscohost.com/login.aspx?direct=true\&db=edswsc\&A $\mathrm{N}=000276564400002 \&$ site=eds-live\&scope=site.

26. Camp DL, Finlay WML, Lyons E. Is low self-esteem an inevitable consequence of stigma? An example from women with chronic mental health problems. Soc Sci Med. 2002;55:823-34.

27. Carlton-Ford S, Miller R, Nealeigh N, Sanchez N. The effects of perceived stigma and psychological over-control on the behavioural problems of children with epilepsy. Seizure. 1997;6(5):383-91. https://doi.org/10.1016/S1 059-1311(97)80038-6.

28. Victorson D, Cavazos JE, Holmes GL, Reder AT, Wojna V, Nowinski C, et al. Validity of the Neurology Quality-of-Life (Neuro-QoL) measurement system in adult epilepsy. Epilepsy Behav. 2014;31:77-84. https://doi.org/10.1016/j. yebeh.2013.11.008.

29. Mogensen L, Mason J. The meaning of a label for teenagers negotiating identity: experiences with autism spectrum disorder. Sociol Health IIIn. 2015; 37(2):255-69. https://doi.org/10.1111/1467-9566.12208.

30. Beaune L, Forrest CR, Keith T. Adolescents' perspectives on living and growing up with Treacher Collins syndrome: a qualitative study. Cleft Palate Craniofac J. 2004;41(4):343-50. https://doi.org/10.1597/02-158.1.

31. Roerink SHPP, Wagenmakers MAEM, Wessels JF, Sterenborg RBTM, Smit JW, Hermus ARMM, et al. Persistent self-consciousness about facial appearance, measured with the Derriford appearance scale 59, in patients after longterm biochemical remission of acromegaly. Pituitary. 2015;18(3):366-75. https://doi.org/10.1007/s11102-014-0583-8.

32. Pandey N. Crouzon syndrome: a social stigma. BMJ Case Rep. 2012; 2012:7242.

33. Mendes Á, Sousa L, Sequeiros J, Clarke A. Discredited legacy: stigma and familial amyloid polyneuropathy in northwestern Portugal. Soc Sci Med. 2017;182:73-80. https://doi.org/10.1016/j.socscimed.2017.04.026.

34. Pascoe EA, Richman LS. Perceived discrimination and health: a meta-analytic review. Psychol Bull. 2009;135(4):531-54. https://doi.org/10.1037/a0016059.

35. Scambler G. Health-related stigma. Sociol Health IIIn. 2009;31(3):441-55. https://doi.org/10.1111/j.1467-9566.2009.01161.x.

36. van der Beek KM, Bos I, Middel B, Wynia K. Experienced stigmatization reduced quality of life of patients with a neuromuscular disease: a crosssectional study. Clin Rehabil. 2013;27(11):1029-38. https://doi.org/10.1177/02 69215513487234.

37. Myung G, Harada ND, Fong SL, Aquino-Beaton C., Fang, MA. Characterization of social stigma in rheumatic diseases and correlation with quality of life and medication adherence. Arthritis \& Rheumatology. 2014;66: S921-S922.

38. Aspinall CL. Do I make you uncomfortable? Reflections on using Suegery to reduce the distress of others. In: Parens $E$, editor. Surgically shaping children: technology, ethics and the pursuit of normality. Baltimore: Johns Hopkins University Press; 2008. p. 13-28.

39. Roberts RM, Shute R. Living with a craniofacial condition: development of the craniofacial experiences questionnaire (CFEQ) for adolescents and their parents. J Pediatr Psychol. 2011;48:727-35.

40. Edwards TC, Patrick DL, Topolski TD, Aspinall CL, Mouradian WE, Speltz ML. Approaches to craniofacial-specific quality of life assessment in adolescents. Cleft Palate Craniofac J. 2005;42(1):19-24. https://doi.org/1 0.1597/03-097.2.1.

41. Geirdal AØ, Saltnes SS, Storhaug K, Åsten P, Nordgarden H, Jensen JL. Living with orofacial conditions: psychological distress and quality of life in adults affected with Treacher Collins syndrome, cherubism, or oligodontia/ ectodermal dysplasia_a comparative study. Qual Life Res. 2015;24(4):92735. https://doi.org/10.1007/s11136-014-0826-1.

42. Patrick DL, Topolski TD, Edwards TC, Aspinall CL, Kapp-Simon KA, Rumsey $\mathrm{NJ}$, et al. Measuring the quality of life of youth with facial differences. Cleft Palate Craniofac J. 2007;44(5):538-47. https://doi.org/10.1597/06-072.1.

43. Hartog K, Hubbard CD, Krouwer AF, Thornicroft G, Kohrt BA, Jordans MJD. Stigma reduction interventions for children and adolescents in low- and 
middle-income countries: systematic review of intervention strategies. Soc Sci Med. 2020;246:112749. https://doi.org/10.1016/j.socscimed.2019.112749.

44. McMaugh A. En/countering disablement in school life in Australia: children talk about peer relations and living with illness and disability. Disabil Soc. 2011;26(7):853-66. https://doi.org/10.1080/09687599.2011.618740.

45. Bakula DM, Sharkey CM, Perez MN, Espeleta HC, Hawkins M, Chaney JM, et al. The role of stigma in the relationship between illness intrusiveness and adjustment in adolescents and young adults: a path model. J Pediatr Psychol. 2019;44(5):611-9. https://doi.org/10.1093/jpepsy/jsz004.

46. Gamwell KL, Baudino MN, Bakula DM, Sharkey CM, Roberts CM, Grunow JE, et al. Perceived illness stigma, thwarted belongingness, and depressive symptoms in youth with inflammatory bowel disease (IBD). Inflamm Bowel Dis. 2018;24(5):960-5. https://doi.org/10.1093/ibd/izy011.

47. Roberts CM, Gamwell KL, Baudino MN, Grunow JE, Jacobs NJ, Tung J, et al. The contributions of illness stigma, health communication difficulties, and thwarted belongingness to depressive symptoms in youth with inflammatory bowel disease. J Pediatr Psychol. 2020:45(1):81-90.

48. Kranke D, Jackson SE, Taylor DA, Landguth J, Floersch J. I'm loving life': adolescents' empowering experiences of living with a mental illness. Qual Soc Work. 2015;14(1):102-18. https://doi.org/10.1177/1473325013510545.

49. Majoor BCJ, Andela CD, Bruggemann J, van de Sande MAJ, Kaptein AA, Hamdy NAT, et al. Determinants of impaired quality of life in patients with fibrous dysplasia. Orphanet J Rare Dis. 2017;12(1):80. https://doi.org/10.1186/ s13023-017-0629-x.

50. Majoor BCJ, Andela CD, Quispel CR, Rotman M, Dijkstra PDS, Hamdy NAT, et al. Illness perceptions are associated with quality of life in patients with fibrous dysplasia. Calcif Tissue Int. 2018;102(1):23-31. https://doi.org/10.1007/ s00223-017-0329-5.

51. Rotman M, Andela CD, Majoor BCJ, Dijkstra PDS, Hamdy NAT, Kaptein AA, et al. Passive coping strategies are associated with more impairment in quality of life in patients with fibrous dysplasia. Calcif Tissue Int. 2018;103(5): 469-75. https://doi.org/10.1007/s00223-018-0441-1.

52. Hagelstein-Rotman M, Genders SW, Andela CD, Dijkstra S, Majoor BCJ, Notting IC, et al. Patients with isolated craniofacial dysplasia report better quality of life compared with those with craniofacial dysplasia and extracranial involvement. Ophthalmic Plast Reconstr Surg. 2020;36(3):292-7. https://doi.org/10.1097//OP.0000000000001536.

53. Burke $A B$, Leroux $B G$, Konradi A. Quality of life and stigma outcomes in the surgical treatment of craniofacial fibrous dysplasia (Poster); 2020.

54. Burke A, Konradi A. To operate or not to operate: quality of life outcomes in craniofacial fibrous dysplasia (Poster). 2020. https://www.eventscribe.com/2 020/AAOMS-Annual/posters/posterthumbview.asp.

55. Fibrous Dysplasia Foundation Patient Registry. www.fdmasregistry.org. Accessed 10 Dec 2020.

56. Neuro QOL - Quality of life in Neurological Disorders - Scoring Manual, Version 2.0 March 2015. http://www.healthmeasures.net/images/neuro_qol/ Neuro_QOL_Scoring_Manual_Mar2015.pdf. Accessed 30 Dec 2019.

57. Lai J-S, Nowinski C, Victorson D, Bode R, Podrabsky T, McKinney N, et al. Quality-of-life measures in children with neurological conditions: pediatric Neuro-QOL. Neurorehabil Neural Repair. 2012;26(1):36-47. https://doi.org/1 $0.1177 / 1545968311412054$

58. Molina Y, Choi SW, Cella D, Rao D. The stigma scale for chronic illnesses 8item version (SSCl-8): development, validation and use across neurological conditions. IntJ Behav Med. 2013;20(3):450-60. https://doi.org/10.1007/s1252 9-012-9243-4.

59. Snaith RP. The hospital anxiety and depression scale. Health Qual Life Outcomes. 2003;1:29-34.

60. Bjelland I, Dahl AA, Haug T, Neckelmann D. The validity of the hospital anxiety and depression scale an updated literature review. J Psychosom Res. 2002;52(2):69-77. https://doi.org/10.1016/S0022-3999(01)00296-3.

61. Cosco TD, Doyle F, Ward M, McGee H. Latent structure of the hospital anxiety and depression scale: a 10-year systematic review. J Psychosom Res. 2012;72(3):180-4. https://doi.org/10.1016/j.jpsychores.2011.06.008.

62. White D, Leach C, Sims R, Atkinson M, Cottrell D. Validation of the hospital anxiety and depression scale for use with adolescents. Br J Psychiatry. 1999; 175(5):452-4. https://doi.org/10.1192/bjp.175.5.452.

63. Jörngården A, Wettergen L, von Essen L. Measuring health-related quality of life in adolescents and young adults: Swedish normative data for the SF-36 and the HADS, and the influence of age, gender, and method of administration. Health Qual Life Outcomes. 2006:4(1):91. https://doi.org/1 $0.1186 / 1477-7525-4-91$
64. Saez-Flores E, Tonarely NA, Barker DH, Quittner AL. Examining the stability of the hospital anxiety and depression scale factor structure in adolescents and young adults with cystic fibrosis: a confirmatory factor analysis. J Pediatr Psychol. 2018;43(6):625-35. https://doi.org/10.1093/jpepsy/jsx155.

65. Berard R, Ahmed N. Hospital anxiety and depression scale (HADS) as a screening instrument in a depressed adolescent and young adult population. Int J Adolesc Med Health. 1995;8:157-66.

66. Heijnders $M$, van der Meij S. The fight against stigma: an overview of stigma-reduction strategies and interventions. Psychol Health Med. 2006; 11(3):353-63. https://doi.org/10.1080/13548500600595327.

67. Lai J-S, Jensen SE, Charrow J, Listernick R. Patient reported outcomes measurement information system and quality of life in neurological disorders measurement system to evaluate quality of life for children and adolescents with neurofibromatosis type 1 associated plexiform neurofibroma. J Pediatr. 2019;206:190-6. https://doi.org/10.1016/j.jpeds.2018.10.019.

68. Alansari R, Bedos C, Allison P. Living with cleft lip and palate: the treatment journey. Cleft Palate Craniofac J. 2014;51(2):222-9. https://doi.org/10.1 597/12-255

69. Ablon J. The nature of stigma and medical conditions. Epilepsy Behav. 2002; 3:S2-9.

70. Krueckeberg SM, Kapp-Simon K. Effect of parental factors on social skills of preschool children with craniofacial anomalies. Cleft Palate Craniofac J. 1993;30(5):490-6. https://doi.org/10.1597/1545-1569_1993_030_0490_ eopfos_2.3.co_2.

71. Carroll L, Graff C, Wicks M, Diaz Thomas A. Living with an invisible illness: a qualitative study exploring the lived experiences of female children with congenital adrenal hyperplasia. Qual Life Res. 2020;29(3):673-81. https://doi. org/10.1007/s11136-019-02350-2.

72. Francis A. Stigma in an era of medicalisation and anxious parenting: how proximity and culpability shape middle-class parents' experiences of disgrace: stigma in an era of medicalisation and anxious parenting. Sociol Health IIIn. 2012:34(6):927-42. https:/doi.org/10.1111/j.1467-9566.2011.01445.x.

73. Manago B, Davis JL, Goar C. Discourse in action: parents' use of medical and social models to resist disability stigma. Soc Sci Med. 2017;184:169-77. https://doi.org/10.1016/j.socscimed.2017.05.015.

74. Fleitas J. Sticks, stones, and the stigmata of childhood illness and disability. Reclaiming Child Youth. 2000;9:146-9.

75. Landsman GH. Reconstructing motherhood in the age of "perfect" babies: mothers of infants and toddlers with disabilities. Signs. 1998;24:69-99.

76. Bessell A, Brough V, Clarke A, Harcourt D, Moss TP, Rumsey N. Evaluation of the effectiveness of Face IT, a computer-based psychosocial intervention for disfigurement-related distress. Psychol Health Med. 2012;17(5):565-77. https://doi.org/10.1080/13548506.2011.647701.

77. Yanos PT, Roe D, Lysaker PH. Narrative enhancement and cognitive therapy: a new group-based treatment for internalized stigma among persons with severe mental illness. Int J Group Psychother. 2011;61(4):577-95. https://doi. org/10.1521/ijgp.2011.61.4.576.

78. Mittal D, Sullivan G, Chekuri L, Allee E, Corrigan PW. Empirical studies of selfstigma reduction strategies: a critical review of the literature. Psychiatr Serv. 2012;63(10):974-81. https://doi.org/10.1176/appi.ps.201100459.

79. Pearl RL, Hopkins CH, Berkowitz RI, Wadden TA. Group cognitive-behavioral treatment for internalized weight stigma: a pilot study. Eat Weigh Disord. 2016;27:1-6.

80. Hansson L, Yanos PT. Narrative enhancement and cognitive therapy: a pilot study of Outomes of a self-stigma intervention in a Swedish clinical context. Stigma Health. 2016;1(4):280-6. https://doi.org/10.1037/sah0000035.

81. KappSimon KA, McGuire DE. Observed social interaction patterns in adolescents with and without craniofacial conditions. Cleft Palate Craniofac J. 1997;34(5):380-4. https://doi.org/10.1597/1545-1569_1997_034_0380_ osipia_2.3.co_2.

82. Rumsey N, Harcourt D. Visible difference amongst children and adolescents: issues and interventions. Dev Neurorehabil. 2007;10(2):113-23. https://doi. org/10.1080/13638490701217396.

83. Maddern LH, Cadogan JC, Emerson MP. "Outlook": a psychological service for children with a different appearance. Cleft Palate Craniofac J. 2006;11: 431-43.

84. Waugh OC, Byrne DG, Nicholas MK. Internalized stigma in people living with chronic pain. J Pain. 2014;15:550.e1-550.e10.

85. Sheng J, Liu S, Wang Y, Cui R, Zhang $X$. The link between depression and chronic pain: neural mechanisms in the brain. Neural Plast. 2017:2017:1-10. https://doi.org/10.1155/2017/9724371. 
86. Naushad N, Dunn LB, Muñoz RF, Leykin Y. Depression increases subjective stigma of chronic pain. J Affect Disord. 2018;229:456-62. https://doi.org/10.1 016/j.jad.2017.12.085

87. Coyne JC, van Sonderen E. The hospital anxiety and depression scale (HADS) is dead, but like Elvis, there will still be citings. J Psychosom Res. 2012;73(1):77-8. https://doi.org/10.1016/j.jpsychores.2012.04.002.

88. Polich GR. Rare disease patient groups as clinical researchers. Drug Discov Today. 2012;17:167-72.

89. Panofsky A, Huyard C, Polich GR, Popoviciu S, Birle D, Olah S, et al. Generating sociability to drive science: patient advocacy organizations and genetics research. Soc Stud Sci. 2008;41:52 17; 36; 7; 11; 31:31; 719; 167; 144; A136; 21-57; +; 172; 161; A137; 29.

90. Huyard C, Polich GR, Popoviciu S, Birle D, Olah S, Popoviciu I. Who rules rare disease associations? A framework to understand their action. Sociol Health IIIn. 2012;17:36 979; 167; 144-72; 161.

\section{Publisher's Note}

Springer Nature remains neutral with regard to jurisdictional claims in published maps and institutional affiliations.

Ready to submit your research? Choose BMC and benefit from:

- fast, convenient online submission

- thorough peer review by experienced researchers in your field

- rapid publication on acceptance

- support for research data, including large and complex data types

- gold Open Access which fosters wider collaboration and increased citations

- maximum visibility for your research: over $100 \mathrm{M}$ website views per year

At BMC, research is always in progress.

Learn more biomedcentral.com/submissions 